\title{
Effects of yeast products on the intestinal morphology, barrier function, cytokine expression, and antioxidant system of weaned piglets"
}

\author{
Huan-sheng YANG ${ }^{\S 1,2,3}$, Fei WU ${ }^{\S 1}$, Li-na LONG ${ }^{1}$, Tie-jun $\mathrm{LI}^{1}$, Xia XIONG ${ }^{\dagger 1,4}$, \\ Peng LIAO ${ }^{1}$, Hong-nan LIU $^{\dagger 1}$, Yu-long YIN $^{1}$ \\ ( ${ }^{1}$ Observation and Experiment Station of Animal Nutrition and Feed Science in South-Central China, Ministry of Agriculture; Hunan Provincial \\ Engineering Research Center for Healthy Livestock and Poultry Production; Key Laboratory of Agro-ecological Processes in Subtropical Region, \\ Institute of Subtropical Agriculture, Chinese Academy of Sciences, Changsha 410125, China) \\ $\left({ }^{2}\right.$ School of Life Sciences, Hunan Normal University, Changsha 410006, China) \\ ( ${ }^{3}$ Fujian Aonong Bio-Technology Co., Ltd., Xiamen 361008, China) \\ $\left({ }^{4}\right.$ National Research Center of Engineering Technology for Utilization of Botanical Functional Ingredients from Botanicals, Provincial \\ Co-Innovation Center for Utilization of Botanical Function Ingredients, Hunan Agricultural University, Changsha 410128, China) \\ †E-mail: xx@isa.ac.cn; liuhn@isa.ac.cn \\ Received Aug. 13, 2015; Revision accepted Feb. 17, 2016; Crosschecked Sept. 11, 2016
}

\begin{abstract}
The goal of this study was to evaluate the effects of a mixture of yeast culture, cell wall hydrolysates, and yeast extracts (collectively "yeast products," YP) on the performance, intestinal physiology, and health of weaned piglets. A total of 90 piglets weaned at $21 \mathrm{~d}$ of age were blocked by body weight, sex, and litter and randomly assigned to one of three treatments for a 14-d feeding experiment, including (1) a basal diet (control), (2) $1.2 \mathrm{~g} / \mathrm{kg}$ of YP, and (3) $20 \mathrm{mg} / \mathrm{kg}$ of colistin sulfate (CSE). No statistically significant differences were observed in average daily feed intake, average daily weight gain, or gain-to-feed ratio among CSE, YP, and control piglets. Increased prevalence of diarrhea was observed among piglets fed the YP diet, whereas diarrhea was less prevalent among those fed CSE. Duodenal and jejunal villus height and duodenal crypt depth were greater in the control group than they were in the YP or CSE groups. Intraepithelial lymphocytes (IEL) in the duodenal and jejunal villi were enhanced by YP, whereas IEL in the ileal villi were reduced in weaned piglets fed YP. Secretion of jejunal and ileal interleukin-10 (IL-10) was higher and intestinal and serum antioxidant indexes were affected by YP and CSE. In YP- and CSE-supplemented animals, serum D-lactate concentration and diamine oxidase (DAO) activity were both increased, and intestinal mRNA expressions of occludin and ZO-1 were reduced as compared to the control animals. In conclusion, YP supplementation in the diets of weaned piglets appears to increase the incidence of diarrhea and has adverse effects on intestinal morphology and barrier function.
\end{abstract}

Key words: Yeast products, Weaned piglet, Intestinal morphology, Barrier function, Antioxidant system http://dx.doi.org/10.1631/jzus.B1500192

CLC number: S828

\footnotetext{
${ }^{\ddagger}$ Corresponding authors

${ }^{\S}$ The two authors contributed equally to this work

* Project supported by the National Natural Science Foundation of China (Nos. 31330075, 31402089, 31301988, 31572420, 31272450, and 31272451), the National Key Technology R \& D Program of China (No. 2016YFD0500504), the Changsha Lvye Biotechnology Limited Company Academician Expert Workstation, the Guangdong Hinapharm Group Academician Workstation for Biological Feed and Feed Additives, and the Animal Intestinal Health Hunan New Wellful Co., Ltd., Academician Workstation, Changsha, China

(1D) ORCID: Hong-nan LIU, http://orcid.org/0000-0002-5710-8624

(c) Zhejiang University and Springer-Verlag Berlin Heidelberg 2016
} 


\section{Introduction}

Weaned piglets face numerous challenges, including diarrhea, impaired growth rates, and low feed intake (Blecha and Charley, 1990; Pluske et al., 1996; Kang et al., 2012). Antibiotics have long been incorporated into the diets of piglets to solve postweaning problems; however, their use increases the potential for antibiotic residues to persist in pork products, and bacterial resistance could be transferred to humans (van den Bogaard and Stobberingh, 2000). As such, many countries have banned the inclusion of antibiotics in the diets of pigs. To maintain the health status and growth performance of weaned piglets, there has been increasing demand to identify safe alternatives to antibiotics. Yeast culture (YC) is a dried product that contains live yeast cells and several metabolic by-products, including enzymes, vitamins, other nutrients, and important co-factors, which are produced during the yeast fermentation process. Previous studies have tested the effects of YC, Calcofluor white-hypersensitive $(\mathrm{CWH})$, and yeast products (YP) on the performance of weaned piglets, demonstrating that they exert positive effects on intestinal function and health and enhance the immune response of piglets. Because $\mathrm{YC}, \mathrm{CWH}$, and yeast extracts (YE) exhibit differential effects on weaning piglets, a mixture of the three YP may therefore have synergistic effects on piglet health. In the present study, we hypothesized that dietary supplementation with YP may have positive effects on the intestinal physiology and health of weaned piglets; thus, the objective of the present study was to examine the growth performance, incidence of diarrhea, intestinal morphology, barrier function, immune response, and antioxidant system of weaned piglets fed a diet supplemented with YP.

\section{Materials and methods}

\subsection{Animals, experimental treatments, and inci- dence of diarrhea}

A total of 90 Duroc $\times$ Landrace $\times$ Yorkshire piglets were weaned at $21 \mathrm{~d}$ of age (average body weight $(B W)=(7.86 \pm 0.22) \mathrm{kg}$ ), and were blocked by BW, sex, and litter and randomly assigned to one of three treatments, including (1) a basal diet, (2) the basal diet supplemented with $1.2 \mathrm{~g} / \mathrm{kg}$ of YP (Shintsen Biological Technology Co., Ltd., Hubei, China), and (3) the basal diet supplemented with $20 \mathrm{mg} / \mathrm{kg}$ of colistin sulfate (CSE), for $14 \mathrm{~d}$. The yeast used was Saccharomyces cerevisiae, and yeast cells were isolated from $\mathrm{YC}$ by centrifugation; cell walls were also isolated by centrifugation after the yeast cell was broken. Isolated cell walls were then hydrolyzed by the enzyme mannase. After drying, all the $\mathrm{YC}, \mathrm{CWH}$, and $\mathrm{YE}$ of a batch fermentation were mixed together to form the YP, the chemical composition of which is presented in Table 1. The cereal-based basal diet (Table 2) met the National Research Council (NRC) nutrient specifications for pigs in the $10-20 \mathrm{~kg} \mathrm{BW}$ range (NRC, 2012). The YP group was fed the basal diet supplemented with $1.2 \mathrm{~g} / \mathrm{kg}$ of YP, and the control and CSE groups were both fed the basal diet supplemented with $0.6 \mathrm{~g} / \mathrm{kg}$ of wheat and $0.6 \mathrm{~g} / \mathrm{kg}$ of soybean meal. There were six pens per experimental diet, with five piglets per pen. Piglets were allowed free access to feed and drinking water at all times during the study (Wu et al., 2010). At 21 and $35 \mathrm{~d}$ of age, piglets were weighed immediately before feeding. Troughs were weighed and feed was added daily to determine pen feed intake. The average daily feed intake (ADFI), average daily gain (ADG), and gain-to-feed ratio (G:F) were calculated per pen, and the incidence of diarrhea in piglets was monitored and recorded daily by the same individual over the course of the study (Yin et al., 2010). The incidence of diarrhea was defined as described by Liu et al. (2008). The incidence of diarrhea was also calculated according to the formula: diarrhea incidence $=$ total number of pigs with diarrhea/ (total number of pigs $\times$ experimental days) $\times 100 \%$, where "total number of pigs with diarrhea" was defined as the number of pigs with diarrhea observed each day (Liu et al., 2008).

Table 1 Chemical composition of the yeast products (YP)

\begin{tabular}{lr}
\hline Component & YP (\%) \\
\hline Moisture & 10.13 \\
Crude protein & 22.84 \\
Crude fat & 2.31 \\
Crude fiber & 7.27 \\
Calcium & 0.17 \\
Phosphorus & 0.63 \\
Ash & 3.88 \\
\hline
\end{tabular}


Table 2 Ingredient and chemical composition of the basal diet (as-fed basis)

\begin{tabular}{lc}
\hline \multicolumn{1}{c}{ Ingredient } & Content (\%) \\
\hline Extruded corn & 28.5 \\
Wheat & 24.5 \\
Extruded soybean & 13.8 \\
Soybean meal & 10.3 \\
Spray-dried whey & 10.0 \\
Fish meal & 4.5 \\
Soy oil & 3.0 \\
Limestone & 0.6 \\
Monocalcium phosphate & 0.6 \\
L-Lys·HCl & 0.4 \\
Salt & 0.3 \\
Vitamin and mineral premix ${ }^{\mathrm{a}}$ & 3.5 \\
Calculated analysis & \\
ME (MJ/kg) & 13.55 \\
CP & 20.00 \\
Total Lys & 1.40 \\
Total Met & 0.35 \\
Total Thr & 0.87 \\
Ca & 0.70 \\
Available P & 0.43 \\
\hline
\end{tabular}

${ }^{a}$ The vitamin-mineral premix supplied per kg of feed: $10000 \mathrm{IU}$ of vitamin $\mathrm{A} ; 1000 \mathrm{IU}$ of vitamin $\mathrm{D}_{3} ; 80 \mathrm{IU}$ of vitamin $\mathrm{E} ; 2.0 \mathrm{mg}$ of vitamin $\mathrm{K}_{3} ; 0.03 \mathrm{mg}$ of vitamin $\mathrm{B}_{12} ; 12 \mathrm{mg}$ of riboflavin; $40 \mathrm{mg}$ of niacin; $25 \mathrm{mg}$ of D-pantothenic acid; $0.25 \mathrm{mg}$ of biotin; $1.6 \mathrm{mg}$ of folic acid; $3.0 \mathrm{mg}$ of thiamine; $2.25 \mathrm{mg}$ of pyridoxine; $300 \mathrm{mg}$ of choline chloride; $150 \mathrm{mg}$ of $\mathrm{Fe}\left(\mathrm{FeSO}_{4}\right) ; 100 \mathrm{mg}$ of $\mathrm{Zn}(\mathrm{ZnO})$; $30 \mathrm{mg}$ of $\mathrm{Mn}\left(\mathrm{MnSO}_{4}\right) ; 25 \mathrm{mg}$ of $\mathrm{Cu}\left(\mathrm{CuSO}_{4}\right) ; 0.5 \mathrm{mg}$ of $\mathrm{I}\left(\mathrm{KIO}_{3}\right)$; $0.3 \mathrm{mg}$ of $\mathrm{Co}\left(\mathrm{CoSO}_{4}\right) ; 0.3 \mathrm{mg}$ of $\mathrm{Se}\left(\mathrm{Na}_{2} \mathrm{SeO}_{3}\right)$; and $4.0 \mathrm{mg}$ of ethoxyquin

\subsection{Sample collection and serum anti-oxidation index, D-lactate, and diamine oxidase analysis}

BW of the piglets was determined at $35 \mathrm{~d}$ of age. Six piglets (three females and three males) from each diet (one piglet per pen) were randomly selected for collection of blood and tissue samples, according to the protocol described by He et al. (2011). Blood samples were collected by jugular venipuncture using 10 -ml tubes, and centrifuged at $3000 \mathrm{~g}$ at $4{ }^{\circ} \mathrm{C}$ for $10 \mathrm{~min}$ to recover serum (Yin et al., 2010). Serum samples were then stored at $-80{ }^{\circ} \mathrm{C}$ until required for further analyses of D-lactate, diamine oxidase (DAO), and the anti-oxidation index. Piglets were then anesthetized (with $\mathrm{C}_{3} \mathrm{H}_{2} \mathrm{ClF}_{5} \mathrm{O}$ ) and euthanized by intravenous administration (jugular vein) of $4 \%$ sodium pentobarbital solution ( $40 \mathrm{mg} / \mathrm{kg} \mathrm{BW}$ ) (Yang et al., 2012). The gastrointestinal tract of euthanized piglets was immediately resected and divided into stomach, duodenum, jejunum, ileum, cecum, and colon. Approximately $20 \mathrm{~cm}$ of intestinal segments were aseptically isolated from the middle sections of the duodenum, jejunum, and ileum. The isolated intestinal segments were then flushed with phosphate-buffered saline and each segment was divided into two sections. One section (about $2 \mathrm{~cm}$ in length) was fixed using a $10 \%$ formaldehyde-phosphate buffer and kept at $4{ }^{\circ} \mathrm{C}$, whereas the other section (approximately $18 \mathrm{~cm}$ in length) was used for mucosal sampling (Wu et al., 2015). Immediately after collection, the mucosal tissue samples were frozen in liquid nitrogen and stored at $-80{ }^{\circ} \mathrm{C}$ until required for further analysis of cytokines, anti-oxidation index, and mRNA expression (Tan et al., 2011; Yang et al., 2013). Serum D-lactate content was measured using a commercial kit (Beijing Leadman Biochemistry Co., Beijing, China) and a Beckman CX4 Chemistry Analyzer (Beckman Coulter, Brea, CA, USA). The serum antioxidation index and DAO activity were determined using corresponding reagent kits (Jiancheng Bioengineering Institute, Nanjing, China) according to the protocol described by Yin et al. (2013).

\subsection{Small intestinal morphology analysis}

The fixed intestinal segments were embedded using low-melt paraffin wax. Three cross-sections of each intestinal segment ( $5 \mu \mathrm{m}$ in thickness) were stained with hematoxylin and eosin. Villus height and crypt depth of each intestinal segment were measured at $40 \times$ magnification using an image processing and analysis system (Version 1, Leica Imaging Systems Ltd., Cambridge, UK). At least ten well-oriented intact villi and their associated crypts were examined in each intestinal section of each piglet. The mean villus height and crypt depth of each section were then calculated per piglet and used for further analysis (Tan et al., 2009).

\subsection{Measurement of cytokines and the anti- oxidation index in intestinal mucosa}

Levels of interleukin-1 $\beta$ (IL-1 $\beta$ ), IL-2, and IL-10 in the intestinal mucosa of piglets were measured using commercially available swine enzyme-linked immunosorbent assay (ELISA) kits according to the manufacturer's instructions (Cusabio Biotech Co., Ltd., Hubei, China). The minimum detectable doses for IL-1 $\beta$, IL-2, and IL-10 were $3.9 \mathrm{pg} / \mathrm{ml}, 15.6 \mathrm{pg} / \mathrm{ml}$, 
and $6.25 \mathrm{pg} / \mathrm{ml}$, respectively. The total antioxidant capacity (T-AOC) of the intestinal mucosa (A015), catalase (CAT) (A007-1) and superoxide dismutase (SOD) (A001-3) activities, and malondialdehyde (MDA) (A003-1) and glutathione (GSH) (reduced, A006-1) contents were assessed using corresponding reagent kits according to the instructions of the manufacturer (Jiancheng Bioengineering Institute) (Ren et al., 2012). Protein concentration was determined by bicinchoninic acid assay (Beyotime Biotechnology, Beijing, China), according to the instructions of the manufacturer. Concentrations of the intestinal mucosal cytokines and the anti-oxidation index were standardized to the concentration of protein in each sample.

\subsection{RNA extraction and cDNA synthesis}

Approximately $100 \mathrm{mg}$ of intestinal mucosa was pulverized using liquid nitrogen, according to the protocol described by Yang et al. (2013). Total RNA was then isolated from the homogenate by the TRIzol $^{\circledR}$ reagent (Invitrogen, Carlsbad, CA, USA) using $100 \mathrm{mg}$ tissue per milliliter TRIzol. The integrity of the RNA was checked using agarose gel electrophoresis with ethidium bromide as the staining agent. The quantity and quality of RNA were determined by ultraviolet spectroscopy using a spectrophotometer (NanoDrop ND-1000; Thermo Fisher Scientific, DE, USA). The RNA had an $\mathrm{OD}_{260}: \mathrm{OD}_{280}$ ratio $\left(\mathrm{OD}_{260}\right.$ and $\mathrm{OD}_{280}$ are the optical densities at 260 and $280 \mathrm{~nm}$, respectively) between 1.8 and 2.0. The RNA $(10 \mu \mathrm{g})$ was incubated with DNase I (Invitrogen) according to the manufacturer's instructions and the treated RNA was then quantified using NanoDrop ND-1000 (Thermo Fisher Scientific). After quantification, $1 \mu \mathrm{g}$ of DNA-free RNA was used for complementary DNA (cDNA) synthesis. First-strand cDNA was synthesized using oligo (dT) primer and Superscript II Reverse Transcriptase (Invitrogen).

\subsection{Relative quantification of mRNA expression of occludin and ZO-1}

Oligo 6.0 software (Molecular Biology Insights, Cascade, CO, USA) was used to design primers, which are listed in Table 3. Real-time quantitative PCR (RT-PCR) analyses were performed using the ABI 7900HT Fast Real-Time PCR System (Applied Biosystems, Carlsbad, CA, USA). Total volume for each PCR was $10 \mu \mathrm{l}$, comprising $5 \mu \mathrm{l} \mathrm{SYBR}$ Green mix, $1 \mu 14 \times$ diluted cDNA, $0.2 \mu$ l each of forward and reverse primers, and $0.2 \mu \mathrm{l}$ ROX Reference Dye $(50 \times)$. Following a pre-denaturation process $(10 \mathrm{~s}$ at $95{ }^{\circ} \mathrm{C}$ ), a total of 40 cycles of amplification (each cycle consisting of $95^{\circ} \mathrm{C}$ for $5 \mathrm{~s}$ and $60{ }^{\circ} \mathrm{C}$ for $20 \mathrm{~s}$ ) were conducted, which was followed by a melting curve program (from $60{ }^{\circ} \mathrm{C}$ to $99{ }^{\circ} \mathrm{C}$ with a heating rate of $0.1{ }^{\circ} \mathrm{C} / \mathrm{s}$, following which the fluorescence was collected). In each sample, glyceraldehyde-3-phosphate dehydrogenase $(G A P D H)$ and $\beta$-actin were used as the reference genes to normalize the expressions of the genes of interest. The relative mRNA expression ratio $(R)$ of each gene of interest was calculated by the following equation: $R=2^{-\Delta \Delta C_{\mathrm{T} \text { sample-control }} \text {, where }}$ $-\Delta \Delta C_{\mathrm{T} \text { sample-control }}=\left(C_{\mathrm{T} \text { sample gene of interest }}-C_{\mathrm{T} \text { reference sample }}\right)^{-}$ ( $\left.C_{\mathrm{T} \text { control gene of interest }}-C_{\mathrm{T} \text { reference control }}\right)$.

The $C_{\mathrm{T}}$ of reference was the mean $C_{\mathrm{T}}$ value of $G A P D H$ and $\beta$-actin. The efficiency of RT-PCR was determined by amplifying a dilution series of cDNA according to the equation $10^{(-1 / \text { slope })}$. The mRNA of reference and interest genes was amplified with comparable efficiencies. In negative controls, the cDNA sample was replaced with water.

\subsection{Statistical analysis}

All data were subjected to one-way analysis of variance (ANOVA) using SAS software (Version 9.2; SAS Institute Inc., Cary, NC, USA). The pen was used as the experimental unit for the analysis of growth

Table 3 Primer sequences for real-time PCR analysis

\begin{tabular}{cllcc}
\hline Gene & Direction & \multicolumn{1}{c}{ Sequence $\left(5^{\prime} \rightarrow 3^{\prime}\right)$} & GenBank accession number & Product size (bp) \\
\hline \multirow{2}{*}{ Occludin } & Forward & ATGCTTTCTCAGCCAGCGTA & NM_001163647.2 & 176 \\
& Reverse & AAGGTTCCATAGCCTCGGTC & & 169 \\
& Forward & GAGGATGGTCACACCGTGGT & XM_003353439.2 & 216 \\
& Reverse & GGAGGATGCTGTTGTCTCGG & & \\
& Forward & TGCGGGACATCAAGGAGAAG & XM_003357928.1 & 140 \\
& Reverse & AGTTGAAGGTGGTCTCGTGG & & \\
& Forward & AAGGAGTAAGAGCCCCTGGA & NM_001206359.1 & \\
& Reverse & TCTGGGATGGAAACTGGAA & & \\
\hline
\end{tabular}


performance and incidence of diarrhea, and the piglet was used as the experimental unit for the analysis of the anti-oxidation index, concentrations of D-lactate and cytokines, DAO activity, intestinal morphology, and mRNA expression. Probability values $<0.05$ were used to indicate statistical significance among means.

\section{Results}

\subsection{Growth performance, incidence of diarrhea, and small intestinal morphology}

Dietary supplementation with CSE and YP from Days 1 to 14 post-weaning had no significant effect on ADG, ADFI, or G:F in weaned piglets (Table 4). The incidence of diarrhea in weaned piglets was

Table 4 Effects of dietary supplementation with YP on growth performance and incidence of diarrhea in weaned piglets

\begin{tabular}{lcccc}
\hline Group & $\begin{array}{c}\text { ADG } \\
(\mathrm{g} / \mathrm{d})\end{array}$ & $\begin{array}{c}\text { ADFI } \\
(\mathrm{g} / \mathrm{d})\end{array}$ & $\begin{array}{c}\text { G:F } \\
(\mathrm{g} / \mathrm{g})\end{array}$ & $\begin{array}{c}\text { Diarrhea rate } \\
(\%)\end{array}$ \\
\hline Control & 261.90 & 378.63 & 0.69 & $4.48^{\mathrm{b}}$ \\
YP & 255.95 & 359.32 & 0.71 & $8.65^{\mathrm{a}}$ \\
CSE & 229.76 & 346.07 & 0.64 & $2.84^{\mathrm{c}}$ \\
\hline SEM & 30.62 & 28.07 & 0.04 & 1.29 \\
$P$-value & 0.560 & 0.580 & 0.190 & 0.010 \\
\hline
\end{tabular}

ADG: average daily gain; ADFI: average daily feed intake; G:F: gain-to-feed ratio; YP: yeast products; CSE: colistin sulfate; SEM: standard error of the mean. ${ }^{\mathrm{a}, \mathrm{b}, \mathrm{c}}$ Means in the same column with different superscript letters are significantly different $(P<0.05)$ increased $(P<0.05)$ following dietary supplementation with YP, but reduced $(P<0.05)$ following dietary supplementation with CSE. Dietary supplementation with CSE and YP reduced $(P<0.05)$ villus height in the duodenum and jejunum, as well as crypt depth in the duodenum; however, no significant differences in villus height, or crypt depth in the ileum, or crypt depth in the jejunum were observed among the various treatments (Table 5). The number of goblet cells per 100 enterocytes was lower $(P<0.05)$ in the duodenal villi of animals fed a CSE-supplemented diet compared to those fed the control or YP-supplemented diets, whereas that in the ileal villi was higher $(P<0.05)$. No significant differences were observed in the number of goblet cells per 100 enterocytes in the jejunal villi (Table 5). The number of Intraepithelial lymphocytes (IEL) per 100 enterocytes was higher $(P<0.05)$ in the duodenal villi of piglets fed YP-supplemented diets in comparison to those fed control or CSEsupplemented diets. The number of IEL per 100 enterocytes was also higher $(P<0.05)$ in the jejunal villi of piglets fed the YP-supplemented diet in comparison to those fed the control diet. However, piglets fed the control diet had a higher $(P<0.05)$ number of IEL per 100 enterocytes in the ileal villi in comparison to those fed CSE- or YP-supplemented diets (Table 5).

\subsection{Intestinal cytokines}

Concentrations of IL-1 $\beta$ and IL-2 were increased $(P<0.05)$ in the ileal mucosa of piglets fed

Table 5 Effects of YP supplementation on the morphology of the small intestine of weaned piglets

\begin{tabular}{|c|c|c|c|c|c|c|c|c|c|}
\hline \multirow{2}{*}{ Group } & \multicolumn{3}{|c|}{ Villus height $(\mu \mathrm{m})$} & \multicolumn{3}{|c|}{ Crypt depth $(\mu \mathrm{m})$} & \multicolumn{3}{|c|}{$\mathrm{VH}: \mathrm{CD}(\mu \mathrm{m}: \mu \mathrm{m})$} \\
\hline & Duodenum & Jejunum & Ileum & Duodenum & Jejunum & Ileum & Duodenum & Jejunum & Ileum \\
\hline Control & $521.13^{\mathrm{a}}$ & $465.59^{\mathrm{a}}$ & 368.71 & $318.12^{\mathrm{a}}$ & 266.07 & 205.05 & 1.64 & 1.75 & 1.80 \\
\hline YP & $458.39^{\mathrm{b}}$ & $367.09^{\mathrm{b}}$ & 351.82 & $256.22^{\mathrm{b}}$ & 253.73 & 219.28 & 1.79 & 1.45 & 1.60 \\
\hline CSE & $439.94^{b}$ & $360.81^{\mathrm{b}}$ & 389.74 & $256.02^{\mathrm{b}}$ & 242.97 & 225.54 & 1.72 & 1.49 & 1.73 \\
\hline SEM & 25.85 & 29.58 & 27.72 & 26.71 & 14.28 & 10.30 & 0.10 & 0.10 & 0.13 \\
\hline$P$-value & 0.030 & 0.010 & 0.590 & 0.030 & 0.340 & 0.320 & 0.330 & 0.080 & 0.140 \\
\hline \multirow{2}{*}{ Group } & \multicolumn{4}{|c|}{ Goblet cells $^{1}$} & \multicolumn{5}{|c|}{ Intraepithelial lymphocytes ${ }^{2}$} \\
\hline & \multicolumn{2}{|c|}{ Duodenum villi } & num villi & Ileum villi & \multicolumn{2}{|c|}{ Duodenum villi } & \multicolumn{2}{|c|}{ Jejunum villi } & Ileum villi \\
\hline Control & \multicolumn{2}{|l|}{$6.58^{\mathrm{a}}$} & 3.92 & \multicolumn{2}{|l|}{$4.17^{b}$} & $5.42^{\mathrm{b}}$ & \multicolumn{2}{|l|}{$9.83^{b}$} & $21.92^{\mathrm{a}}$ \\
\hline YP & \multicolumn{2}{|l|}{$7.25^{\mathrm{a}}$} & 2.92 & \multicolumn{2}{|l|}{$4.42^{\mathrm{b}}$} & $9.42^{\mathrm{a}}$ & \multicolumn{2}{|l|}{$11.25^{\mathrm{a}}$} & $12.92^{\mathrm{b}}$ \\
\hline CSE & \multicolumn{2}{|l|}{$4.60^{\mathrm{b}}$} & 3.70 & \multicolumn{2}{|l|}{$6.33^{\mathrm{a}}$} & $6.67^{\mathrm{b}}$ & \multicolumn{2}{|l|}{$10.75^{\mathrm{ab}}$} & $12.75^{\mathrm{b}}$ \\
\hline SEM & \multicolumn{2}{|l|}{0.68} & 0.37 & 0.48 & \multicolumn{2}{|r|}{0.68} & \multicolumn{3}{|r|}{1.95} \\
\hline$P$-value & \multicolumn{2}{|l|}{0.030} & 0.120 & \multicolumn{2}{|l|}{0.002} & 0.002 & \multicolumn{2}{|l|}{0.050} & 0.005 \\
\hline
\end{tabular}

VH:CD: villus height:crypt depth; YP: yeast products; CSE: colistin sulfate; SEM: standard error of the mean. ${ }^{\text {a, }}{ }^{\text {Means }}$ in the same column with different superscript letters are significantly different $(P<0.05) .{ }^{1}$ Goblet cells per 100 enterocytes. ${ }^{2}$ Intraepithelial lymphocytes per 100 enterocytes 
CSE-supplemented diets in comparison to those fed the control or YP-supplemented diets. Treatment effects on duodenal and jejunal IL-1 $\beta$ and IL-2 concentrations were not observed. The concentration of IL-10 was higher $(P<0.05)$ in the duodenal mucosa of piglets fed CSE-supplemented diets than that in those fed the control or YP-supplemented diets. Concentrations of IL-10 were significantly higher $(P<0.05)$ in the jejunal mucosa of piglets fed CSE- and YPsupplemented diets in comparison to those fed the control diet, and concentrations of IL-10 were significantly higher $(P<0.05)$ in the ileal mucosa of piglets fed YP-supplemented diets in comparison to those fed the control diet (Table 6).

\subsection{Anti-oxidation index}

Duodenal, ileal, and serum T-AOC was increased $(P<0.05)$ in piglets fed CSE- and YPsupplemented diets in comparison to those fed the control diet; however, piglets fed the CSEsupplemented diet had a higher $(P<0.05)$ jejunal T-AOC than those fed the YP-supplemented diet. An increase $(P<0.05)$ in duodenal and jejunal CAT was observed in piglets fed the YP-supplemented diet compared to those fed the control or CSEsupplemented diets. Serum CAT was also higher $(P<0.05)$ in animals fed the YP-supplemented diet compared to those fed the control diet. Jejunal SOD was decreased $(P<0.05)$ following dietary supplementation with YP. Piglets that were fed YP- or CSEsupplemented diets yielded greater levels of $(P<0.05)$ serum SOD than those fed the control diet. Dietary supplementation with YP increased $(P<0.05)$ ileal GSH in weaned piglets. No differences in duodenal, jejunal, and serum GSH were observed among the various treatments. The concentrations of MDA in the jejunum and ileum declined $(P<0.05)$ in piglets fed YP- and CSE-supplemented diets compared to those

Table 6 Effects of YP supplementation on intestinal IL-1ß, IL-2, and IL-10 concentrations in weaned piglets

\begin{tabular}{|c|c|c|c|c|c|c|c|c|c|}
\hline \multirow{2}{*}{ Group } & \multicolumn{3}{|c|}{ IL-1 $\beta$ (pg/g of protein) } & \multicolumn{3}{|c|}{ IL-2 (pg/g of protein) } & \multicolumn{3}{|c|}{ IL-10 (pg/g of protein) } \\
\hline & Duodenum & Jejunum & Ileum & Duodenum & Jejunum & Ileum & Duodenum & Jejunum & Ileum \\
\hline Control & 83.89 & 13.50 & $11.57^{\mathrm{b}}$ & 117.24 & 120.18 & $117.81^{\mathrm{b}}$ & $205.30^{\mathrm{b}}$ & $87.57^{b}$ & $178.64^{\mathrm{b}}$ \\
\hline YP & 82.81 & 12.30 & $13.06^{\mathrm{b}}$ & 121.25 & 128.71 & $119.67^{b}$ & $214.49^{\mathrm{b}}$ & $126.46^{\mathrm{a}}$ & $241.51^{\mathrm{a}}$ \\
\hline CSE & 95.46 & 15.91 & $20.25^{\mathrm{a}}$ & 116.84 & 117.03 & $135.60^{\mathrm{a}}$ & $275.98^{\mathrm{a}}$ & $124.14^{\mathrm{a}}$ & $211.08^{\mathrm{ab}}$ \\
\hline SEM & 6.34 & 1.68 & 1.48 & 3.19 & 6.06 & 5.10 & 17.62 & 9.62 & 15.02 \\
\hline$P$-value & 0.550 & 0.340 & 0.020 & 0.610 & 0.140 & 0.040 & 0.040 & 0.010 & 0.040 \\
\hline
\end{tabular}

YP: yeast products; CSE: colistin sulfate; SEM: standard error of the mean. ${ }^{\mathrm{a}, \mathrm{b}}$ Means in the same column with different superscript letters are significantly different $(P<0.05)$

Table 7 Effects of YP supplementation on serum and intestinal mucosal anti-oxidation index of weaned piglets

\begin{tabular}{|c|c|c|c|c|c|c|c|c|c|c|}
\hline \multirow{2}{*}{ Group } & \multicolumn{4}{|c|}{$\begin{array}{l}\text { Total antioxidant capacity } \\
\text { (U/g of protein) }\end{array}$} & \multicolumn{4}{|c|}{$\begin{array}{c}\text { Catalase } \\
\text { (U/g of protein) }\end{array}$} & \multicolumn{2}{|c|}{$\begin{array}{l}\text { Superoxide dismutase } \\
\text { (U/g of protein) }\end{array}$} \\
\hline & Duodenum & Jejunum & Ileum & Serum $^{1}$ & Duodenum & Jejunum & Ileum & Serum $^{2}$ & Duodenum & Jejunum \\
\hline Control & $246.39^{c}$ & $487.57^{\mathrm{ab}}$ & $486.33^{b}$ & $1.66^{\mathrm{c}}$ & $412.85^{\mathrm{b}}$ & $294.66^{b}$ & 276.95 & $22.81^{b}$ & 240.86 & $260.88^{\mathrm{a}}$ \\
\hline YP & $454.43^{b}$ & $413.88^{b}$ & $581.83^{\mathrm{a}}$ & $3.74^{\mathrm{a}}$ & $539.63^{\mathrm{a}}$ & $405.11^{\mathrm{a}}$ & 298.49 & $30.61^{\mathrm{a}}$ & 224.79 & $212.02^{\mathrm{b}}$ \\
\hline CSE & $583.27^{\mathrm{a}}$ & $574.32^{\mathrm{a}}$ & $659.07^{\mathrm{a}}$ & $2.87^{\mathrm{b}}$ & $445.34^{\mathrm{b}}$ & $241.28^{\mathrm{b}}$ & 289.15 & $25.73^{\mathrm{ab}}$ & 248.43 & $252.22^{\mathrm{a}}$ \\
\hline SEM & 37.90 & 55.41 & 40.52 & 0.24 & 35.90 & 42.14 & 30.53 & 2.12 & 21.46 & 12.64 \\
\hline$P$-value & 0.001 & 0.030 & 0.040 & 0.001 & 0.030 & 0.020 & 0.780 & 0.050 & 0.610 & 0.010 \\
\hline \multirow[t]{2}{*}{ Group } & \multicolumn{2}{|c|}{$\begin{array}{l}\text { Superoxide dismutase } \\
\text { (U/g of protein) }\end{array}$} & \multicolumn{4}{|c|}{$\begin{array}{c}\text { Glutathione } \\
(\mu \mathrm{mol} / \mathrm{g} \text { of protein })\end{array}$} & \multicolumn{4}{|c|}{$\begin{array}{l}\text { Malondialdehyde } \\
\text { (nmol/g of protein) }\end{array}$} \\
\hline & Ileum & Serum $^{1}$ & Duodenum & Jejunum & Ileum & Serum $^{3}$ & Duodenum & Jejunum & Ileum & Serum $^{4}$ \\
\hline Control & 208.73 & $44.11^{\mathrm{b}}$ & 1.59 & 1.46 & $1.68^{\mathrm{b}}$ & 3.59 & 92.49 & $97.97^{\mathrm{a}}$ & $93.22^{\mathrm{a}}$ & $5.19^{\mathrm{a}}$ \\
\hline YP & 189.17 & $72.03^{\mathrm{a}}$ & 1.78 & 1.54 & $2.21^{\mathrm{a}}$ & 3.30 & 89.50 & $74.66^{\mathrm{b}}$ & $59.32^{\mathrm{b}}$ & $3.36^{\mathrm{b}}$ \\
\hline CSE & 161.71 & $76.41^{\mathrm{a}}$ & 1.62 & 1.36 & $1.67^{\mathrm{b}}$ & 3.93 & 73.57 & $65.96^{\mathrm{b}}$ & $69.30^{\mathrm{b}}$ & $4.83^{\mathrm{a}}$ \\
\hline SEM & 22.81 & 6.76 & 0.17 & 0.15 & 0.18 & 0.31 & 8.16 & 7.28 & 6.23 & 0.35 \\
\hline$P$-value & 0.210 & 0.003 & 0.630 & 0.650 & 0.040 & 0.250 & 0.150 & 0.010 & 0.003 & 0.003 \\
\hline
\end{tabular}

YP: yeast products; CSE: colistin sulfate; SEM: standard error of the mean. ${ }^{\mathrm{a}, \mathrm{b}, \mathrm{c}}$ Means in the same column with different superscript letters are significantly different $(P<0.05) .{ }^{1} \mathrm{U} / \mathrm{ml} ;{ }^{2} \mathrm{U} / \mathrm{L} ;{ }^{3} \mu \mathrm{mol} / \mathrm{L} ;{ }^{4} \mathrm{nmol} / \mathrm{ml}$ 
fed the control diet, and animals fed the YPsupplemented diet had lower $(P<0.05)$ concentrations of serum MDA than those fed the control or CSEsupplemented diets (Table 7).

\subsection{Intestinal barrier function}

Serum D-lactate concentration and DAO activity were both increased $(P<0.05)$ following dietary supplementation with YP and CSE (Table 8). The expression levels of occludin were reduced $(P<0.05)$ in the jejunum and ileum of piglets fed CSE- and YP-supplemented diets, respectively, in comparison to those fed the control diet. Jejunal ZO-1 expression was also down-regulated $(P<0.05)$ by $\mathrm{YP}$ and CSE supplementation, and piglets fed the YPsupplemented diet yielded a lower $(P<0.05)$ expression level of ileal $Z O-1$ than did those fed the control and CSE-supplemented diets (Table 8).

Table 8 Effects of YP supplementation on serum D-lactate concentration, DAO activity, and intestinal occludin and ZO-1 mRNA expression in weaned piglets

\begin{tabular}{lcccccccc}
\hline \multirow{2}{*}{ Group } & \multirow{2}{*}{$\begin{array}{c}\text { D-Lactate } \\
(\mu \mathrm{g} / \mathrm{ml})\end{array}$} & $(\mathrm{U} / \mathrm{L})$ & \multicolumn{2}{c}{ Occludin } & & \multicolumn{2}{c}{$Z O-1$} \\
\cline { 5 - 6 } \cline { 5 - 7 } & & Jejunum & Ileum & & Jejunum & Ileum \\
\hline Control & $8.90^{\mathrm{b}}$ & $13.15^{\mathrm{b}}$ & $1.00^{\mathrm{a}}$ & $1.00^{\mathrm{a}}$ & & $1.00^{\mathrm{a}}$ & $1.00^{\mathrm{a}}$ \\
$\mathrm{YP}$ & $10.90^{\mathrm{a}}$ & $16.41^{\mathrm{a}}$ & $0.81^{\mathrm{ab}}$ & $0.78^{\mathrm{b}}$ & & $0.78^{\mathrm{b}}$ & $0.74^{\mathrm{b}}$ \\
$\mathrm{CSE}$ & $10.67^{\mathrm{a}}$ & $15.83^{\mathrm{a}}$ & $0.73^{\mathrm{b}}$ & $0.92^{\mathrm{ab}}$ & & $0.65^{\mathrm{c}}$ & $0.91^{\mathrm{a}}$ \\
\hline SEM & 0.46 & 0.77 & 0.06 & 0.06 & & 0.05 & 0.05 \\
$P$-value & 0.001 & 0.005 & 0.010 & 0.030 & & 0.001 & 0.010 \\
\hline
\end{tabular}

DAO: diamine oxidase; YP: yeast products; CSE: colistin sulfate; SEM: standard error of the mean. ${ }^{\mathrm{a}, \mathrm{b}}$ Means in the same column with different superscript letters are significantly different $(P<0.05)$

\section{Discussion}

At 2 weeks post-weaning, no significant differences were observed in ADG, ADFI, and G:F among piglets fed the CSE, YP, and control diets. Although several studies have shown that the inclusion of YC, YE, or yeast cell products has positive effects on the ADG of weaned piglets (Maribo and Spring, 2003; Carlson et al., 2005; Hahn et al., 2006; Kogan and Kocher, 2007; Shen et al., 2009), van der PeetSchwering et al. (2007) reported that the ADG of weaned piglets is not significantly affected by antibiotics and $\mathrm{YC}+$ cell wall products at 2 weeks post-weaning. We speculate that the effects of YC and yeast cell wall products on ADG were attenuated after being combined in the YP mixture. Moreover, dietary supplementation with YP increased the incidence of diarrhea in weaning piglets, and to our knowledge, no reports about the influence of YC, YE, or $\mathrm{CWH}$ on the incidence of diarrhea in weaning piglets have been published. The reduction of the positive effects of $\mathrm{YC}, \mathrm{YE}$, and $\mathrm{CWH}$ on the growth performance of piglets could be attributed to the fact that the gut health of piglets was likely adversely affected by the mixture of YC, YE, and CWH. Future studies should be conducted to test the interactions among YC, YE, and CWH. Although CSE has been widely accepted as a growth promoter in swine production, the present results demonstrate that it does not significantly affect the growth performance of weaning piglets. This finding could be attributed to colistin resistance or the fact that the dosage of CSE administered in the present study was very low $(20 \mathrm{mg} / \mathrm{kg})$, which was below the minimum dosage to improve growth performance. Moreover, although there were no statistically significant differences in growth performance among CSE, YP, and control groups, the G:F in the CSE group was about $5 \%$ and $7 \%$ lower than the control and YP groups, respectively. The lower G:F of CSE piglets was probably due to the fact that CSE animals had the lower feed intake and lower ADG.

Diarrhea usually follows some form of intestinal dysfunction arising from significant post-weaning changes in intestinal morphology, including an increase in crypt depth and a reduction in villus height, as has been observed in several studies (Boudry et al., 2004; Montagne et al., 2007; Verdonk et al., 2007). Atrophy of the villi could be attributed to an increase in cell apoptosis, which is induced by cellular factors or endogenous stressors, and further regulates crypt height by promoting crypt cell proliferation (Jiang et al., 2000; Fleck and Carey, 2005). Shen et al. (2009) reported that dietary YC increased villus height and the villus:crypt ratio in the jejunum of weaned piglets; however, van der Peet-Schwering et al. (2007) observed no changes in jejunal morphology when $\mathrm{YC}$ or $\mathrm{YC}+$ cell wall products were included in the diets of piglets. In the present study, we observed that villus height in both the duodenum and jejunum, as well as the duodenal crypt depth, were reduced in piglets fed a diet supplemented with YP. The variable effects of $\mathrm{YP}$ in weaned piglets may be due to differences in the 
live yeast contents of the diet, feeding environment, and piglet weaning age (van Heugten et al., 2003). Although CSE and YP had similar effects on the intestinal morphology of weaned piglets, YP supplementation increased the incidence of diarrhea, whereas CSE supplementation had the opposite effect, possibly because CSE inhibits reproduction of the bacteria that cause diarrhea. Interspersed among the absorptive epithelial cells of the intestine, IEL and goblet cells are involved in preventing both bacterial overgrowth and the penetration of potential pathogens into epithelium. Because YC, yeast cell wall products, and antibiotics have been reported to affect the gastrointestinal bacterial community of weaned piglets (van der Peet-Schwering et al., 2007; Shen et al., 2009), variations in IEL and goblet cell abundance could occur in response to changes in the epithelium of the microbiota.

The epithelium of the intestinal mucosa acts as a physical barrier that helps to block pathogens, while allowing dietary nutrients to enter the body (Sun et al., 1998). An intact intestinal mucosal barrier is therefore very important for proper intestinal function. D-Lactate and DAO are two important markers of mucosal integrity in the intestine, because serum D-lactate concentration increases and DAO activity intensifies when the mucosa is damaged (Luk et al., 1980; Vella and Farrugia, 1998). Both serum D-lactate concentration and DAO activity were increased in YP-treated piglets, suggesting that the intestinal mucosal barrier was also damaged following dietary supplementation with YP, which is consistent with the changes observed in intestinal morphology and the incidence of diarrhea. The mRNA expression levels of the tight junction proteins $o c$ cludin and ZO-1 were also lower in piglets fed the YP-supplemented diet than in piglets fed the control diet. In a previous study, van der Peet-Schwering et al. (2007) reported that dietary supplementation with YP and YC did not affect the integrity of the small intestine, as indicated by levels of plasma intestinal fatty acid binding protein (I-FABP). The disparity in results between the two studies may be explained by differences in the age at weaning.

Weaning stress is associated with oxidative stress, which is considered a major factor affecting intestinal health and function (Kaplan et al., 2007; Wang et al., 2008). Antioxidant enzymes, such as
CAT, SOD, and GSH are important components of the antioxidant system, which is involved in protecting cells from oxidative stress (Irshad and Chaudhuri, 2002). Thus, functioning of the antioxidant system can be assessed by examining the activity of antioxidant enzymes and the concentration of GSH. Although dietary supplementation with YP exerted adverse effects on the incidence of diarrhea, intestinal morphology, and barrier function, the intestinal and serum antioxidant systems of weaned piglets (as indicated by the changes in T-AOC, antioxidant enzyme activities, and GSH and MDA concentrations in the intestinal mucosa and serum) were affected in piglets fed a diet supplemented with YP. These findings are consistent with previous reports of various in vitro and in vivo experimental models in which yeast polysaccharides exhibited antioxidant properties (Kogan et al., 2005; Pourahmad et al., 2011). As diarrhea is usually associated with oxidative stress, which activates the antioxidant system (Granot and Kohen, 2004), this activation in piglets fed the YP-supplemented diet may have resulted from the negative effects of YP on the gut health of weaned piglets. Early weaning results in a sudden cessation of passive immunity from the milk of sows, when the immune system of piglets is still immature, making them vulnerable to diseases such as diarrhea (Ushida et al., 2008). Dietary supplementation with specific nutrients or immunomodulators could improve the performance and health of weaning piglets (Jiang et al., 2009). Cytokines are small peptides that play important roles in the regulation of immune and inflammatory responses (Pié et al., 2004). Proinflammatory cytokines (e.g., IL-1 $\beta$, IL-2, and tumor necrosis factor $\alpha(\mathrm{TNF} \alpha)$ ) are necessary to initiate the inflammatory response during infection; however, overexpression of these cytokines can affect pathological responses (Clark, 2007; Zelnickova et al., 2008). Anti-inflammatory cytokines (e.g., IL-10 and IL-4) are capable of inhibiting the overexpression of pro-inflammatory cytokines and other mediators that could lead to hyper-activation of immune responses in weaned piglets (King et al., 2003; Schiepers et al., 2005). Piglets fed a diet supplemented with YP exhibited lower levels of ileal IL-1 $\beta$ and IL-2 than those fed a diet supplemented with CSE. In addition, the levels of IL-10 in the jejunum and ileum of piglets fed the YP-supplemented diet were greater than those of 
piglets fed the control diet, suggesting that YP influences the immune response of weaned piglets. These results are consistent with previous reports of stimulation of the immune response of weaned piglets following dietary supplementation with yeast cell wall products or specific polysaccharides (Hahn et al., 2006). Moreover, stimulation of the immune response by YP was very likely due to its effects on the intestinal health of weaned piglets, as those fed YPsupplemented diets yielded a higher incidence rate of diarrhea. In addition, the immune system was likely more reactive in piglets with diarrhea. As dysfunction of the large intestine is also a major cause of diarrhea, additional research is needed to test the effects of YP on the large intestine of weaned piglets.

\section{Conclusions}

The results of our study suggest that supplementation of YP in the diets of weaned piglets has negative effects on the incidence of diarrhea, intestinal morphology, and barrier function. Moreover, the mucosal immune system and antioxidant system in the small intestine of piglets were also affected by dietary supplementation with YP. Additional research that incorporates factors such as weaning age and the effects on the large intestine is warranted to gain a better understanding of the effects of YP on weaned piglets.

\section{Compliance with ethics guidelines}

Huan-sheng YANG, Fei WU, Li-na LONG, Tie-jun LI, Xia XIONG, Peng LIAO, Hong-nan LIU, and Yu-long YIN declare that they have no conflicts of interest.

All institutional and national guidelines for the care and use of laboratory animals were followed.

\section{References}

Blecha, F., Charley, B., 1990. Rationale for using immunopotentiators in domestic food animals. Adv. Vet. Sci. Comp. Med., 35:3-19.

http://dx.doi.org/10.1016/B978-0-12-039235-3.50007-1

Boudry, G., Péron, V., le Huërou-Luron, I., et al., 2004. Weaning induces both transient and long-lasting modifications of absorptive, secretory, and barrier properties of piglet intestine. J. Nutr., 134:2256-2262.

Carlson, M.S., Veum, T.L., Turk, J.R., 2005. Effects of yeast extract versus animal plasma in weanling pig diets on growth performance and intestinal morphology. J. Swine
Health Prod., 13:204-209.

Clark, I.A., 2007. How TNF was recognized as a key mechanism of disease. Cytokine Growth Factor Rev., 18(3-4): 335-343. http://dx.doi.org/10.1016/j.cytogfr.2007.04.002

Fleck, C.C., Carey, H.V., 2005. Modulation of apoptotic pathways in intestinal mucosa during hibernation. AJP Regul. Integr. Comp. Physiol., 289(2):R586-R595. http://dx.doi.org/10.1152/ajpregu.00100.2005

Granot, E., Kohen, R., 2004. Oxidative stress in childhood-in health and disease states. Clin. Nutr., 23(1):3-11. http://dx.doi.org/10.1016/S0261-5614(03)00097-9

Hahn, T.W., Lohakare, J.D., Lee, S.L., et al., 2006. Effects of supplementation of $\beta$-glucans on growth performance, nutrient digestibility, and immunity in weanling pigs. $J$. Anim. Sci., 84(6):1422-1428. http://dx.doi.org/10.2527/2006.8461422x

He, Q.H., Tang, H.R., Ren, P.P., et al., 2011. Dietary supplementation with L-arginine partially counteracts serum metabonome induced by weaning stress in piglets. $J$. Proteome Res., 10(11):5214-5221. http://dx.doi.org/10.1021/pr200688u

Irshad, M., Chaudhuri, P.S., 2002. Oxidant-antioxidant system: role and significance in human body. Indian J. Exp. Biol., 40(11):1233-1239.

Jiang, R., Chang, X., Stoll, B., et al., 2000. Dietary plasma protein reduces small intestinal growth and lamina propria cell density in early weaned pigs. J. Nutr., 130(1): 21-26.

Jiang, Z.Y., Sun, L.H., Lin, Y.C., et al., 2009. Effects of dietary glycyl-glutamine on growth performance, small intestinal integrity, and immune responses of weaning piglets challenged with lipopolysaccharide. J. Anim. Sci., 87(12):4050-4056. http://dx.doi.org/10.2527/jas.2008-1120

Kang, P., Wang, M., Hou, Y.Q., et al., 2012. Effects of oral administration of spermine on the development of small intestine and growth performance of weaned pigs. J. Anim. Vet. $A d v$., 11(15):2782-2787. http://dx.doi.org/10.3923/javaa.2012.2782.2787

Kaplan, M., Mutlu, E.A., Benson, M., et al., 2007. Use of herbal preparations in the treatment of oxidant-mediated inflammatory disorders. Complement. Ther. Med., 15(3): 207-216. http://dx.doi.org/10.1016/j.ctim.2006.06.005

King, M.R., Kelly, D., Morel, P.C.H., et al., 2003. Aspects of intestinal immunity in the pig around weaning. In: Pluske, J.R., Dividich, J.L., Verstegen, M.W.A. (Eds.), Weaning the Pig: Concepts and Consequences. Wageningen Academic Publishers, the Netherlands, p.219-257.

Kogan, G., Kocher, A., 2007. Role of yeast cell wall polysaccharides in pig nutrition and health protection. Livest. Sci., 109(1-3):161-165. http://dx.doi.org/10.1016/j.livsci.2007.01.134

Kogan, G., Staško, A., Bauerová, K., et al., 2005. Antioxidant 
properties of yeast $(1 \rightarrow 3)-\beta$-D-glucan studied by electron paramagnetic resonance spectroscopy and its activity in the adjuvant arthritis. Carbohyd. Polym., 61(1):18-28. http://dx.doi.org/10.1016/j.carbpol.2005.02.010

Liu, P., Piao, X.S., Kim, S.W., et al., 2008. Effects of chitooligosaccharide supplementation on the growth performance, nutrient digestibility, intestinal morphology, and fecal shedding of Escherichia coli and Lactobacillus in weaning pigs. J. Anim. Sci., 86(10):2609-2618. http://dx.doi.org/10.2527/jas.2007-0668

Luk, G.D., Bayless, T.M., Baylin, S.B., 1980. Diamine oxidase (histaminase): a circulating marker for rat intestinal mucosal maturation and integrity. J. Clin. Invest., 66(1): 66-70. http://dx.doi.org/10.1172/JCI109836

Maribo, H., Spring, P., 2003. Yeast extract as a protein source for weaning piglets. In: Schubert, R., Flachowsky, G., Jahreis, G., et al. (Eds.), Vitamine und Zusatzstoffe in der Ernährung von Mensch und Tier. Jena Thüringen, p.433-437.

Montagne, L., Boudry, G., Favier, C., et al., 2007. Main intestinal markers associated with the changes in gut architecture and function in piglets after weaning. Brit. J. Nutr., 97(1):45-57. http://dx.doi.org/10.1017/S000711450720580X

NRC (National Research Council), 2012. Nutrient Requirements of Swine: eleventh revised Ed. National Academic Press, Washington, DC. http://dx.doi.org/10.17226/13298

Pié, S., Lallès, J.P., Blazy, F., et al., 2004. Weaning is associated with an upregulation of expression of inflammatory cytokines in the intestine of piglets. J. Nutr., 134(3): 641-647.

Pluske, J.R., Williams, I.H., Aherne, F.X., 1996. Nutrition of the neonatal pig. In: Varley, M.A. (Ed.), The Neonatal Pig: Development and Survival. CAB Int., Wallingford, p.187-235.

Pourahmad, J., Shaki, F., Tanbakosazan, F., et al., 2011. Protective effects of fungal $\beta$ - $(1 \rightarrow 3)$-D-glucan against oxidative stress cytotoxicity induced by depleted uranium in isolated rat hepatocytes. Human Exp. Toxicol., 30(3): 173-181. http://dx.doi.org/10.1177/0960327110372643

Ren, W.K., Yin, Y.L., Liu, G., et al., 2012. Effect of dietary arginine supplementation on reproductive performance of mice with porcine circovirus type 2 (PCV2) infection. Amino Acids, 42(6):2089-2094. http://dx.doi.org/10.1007/s00726-011-0942-y

Schiepers, O.J., Wichers, M.C., Maes, M., 2005. Cytokines and major depression. Prog. Neuro-Psychopharmacol. Biol. Psychiatry, 29(2):201-217. http://dx.doi.org/10.1016/j.pnpbp.2004.11.003

Shen, Y.B., Piao, X.S., Kim, S.W., et al., 2009. Effects of yeast culture supplementation on growth performance, intestinal health, and immune response of nursery pigs. J. Anim.
Sci., 87(8):2614-2624.

http://dx.doi.org/10.2527/jas.2008-1512

Sun, Z.W., Wang, X.D., Andersson, R., 1998. Role of intestinal permeability in monitoring mucosal barrier function. Digest. Surg., 15(5):386-397. http://dx.doi.org/10.1159/000018651

Tan, B.E., Yin, Y.L., Liu, Z.Q., et al., 2009. Dietary L-arginine supplementation increases muscle gain and reduces body fat mass in growing-finishing pigs. Amino Acids, 37(1): 169-175. http://dx.doi.org/10.1007/s00726-008-0148-0

Tan, B.E., Yin, Y.L., Liu, Z.Q., et al., 2011. Dietary L-arginine supplementation differentially regulates expression of fat-metabolic genes in porcine adipose tissue and skeletal muscle. J. Nutr. Biochem., 22(5):441-445. http://dx.doi.org/10.1016/j.jnutbio.2010.03.012

Ushida, K., Kameue, C., Tsukahara, T., et al., 2008. Decreasing traits of fecal immunoglobulin $\mathrm{A}$ in neonatal and weaning piglets. J. Vet. Med. Sci., 70(8):849-852. http://dx.doi.org/10.1292/jvms.70.849

van den Bogaard, A.E., Stobberingh, E.E., 2000. Epidemiology of resistance to antibiotics: links between animals and humans. Int. J. Antimicrob. Agents, 14(4):327-335. http://dx.doi.org/10.1016/S0924-8579(00)00145-X

van der Peet-Schwering, C.M., Jansman, A.J., Smidt, H., et al., 2007. Effects of yeast culture on performance, gut integrity, and blood cell composition of weanling pigs. J. Anim. Sci., 85(11):3099-3109. http://dx.doi.org/10.2527/jas.2007-0110

van Heugten, E., Funderburke, D.W., Dorton, K.L., 2003. Growth performance, nutrient digestibility, and fecal microflora in weanling pigs fed live yeast. J. Anim. Sci., 81(4):1004-1012. http://dx.doi.org/10.2527/2003.8141004x

Vella, A., Farrugia, G., 1998. D-Lactic acidosis: pathologic consequence of saprophytism. Mayo Clin. Proc., 73(5): 451-456. http://dx.doi.org/10.1016/S0025-6196(11)63729-4

Verdonk, J.M., Bruininx, E.M., van der Meulen, J., et al., 2007. Post-weaning feed intake level modulates gut morphology but not gut permeability in weaned piglets. Livest. Sci., 108(1-3):146-149. http://dx.doi.org/10.1016/j.livsci.2007.01.093

Wang, J., Chen, L., Li, P., et al., 2008. Gene expression is altered in piglet small intestine by weaning and dietary glutamine supplementation. J. Nutr., 138(11):1025-1032. http://dx.doi.org/10.3945/jn.108.091009

Wu, X., Yin, Y.L., Li, T.J., et al., 2010. Dietary supplementation with L-arginine or $\mathrm{N}$-carbamylglutamate enhances intestinal growth and heat shock protein-70 expression in weanling pigs fed a corn- and soybean meal-based diet. Amino Acids, 39(3):831-839. http://dx.doi.org/10.1007/s00726-010-0538-y

Wu, X., Zhang, Y., Liu, Z., et al., 2015. Effects of oral supplementation with glutamate or combination of glutamate 
and $N$-carbamylglutamate on intestinal mucosa in piglets. J. Anim. Sci., 90(Suppl. 4):337-339.

http://dx.doi.org/10.2527/jas.53752

Yang, H., Fu, D., Shao, H., et al., 2012. Impacts of birth weight on plasma, liver and skeletal muscle neutral amino acid profiles and intestinal amino acid transporters in suckling Huanjiang mini-piglets. PLOS ONE, 7:e50921. http://dx.doi.org/10.1371/journal.pone.0050921

Yang, H., Li, F., Xiong, X., et al., 2013. Soy isoflavones modulate adipokines and myokines to regulate lipid metabolism in adipose tissue, skeletal muscle and liver of male Huanjiang mini-pigs. Mol. Cell. Endocrinol., 365(1): 44-51. http://dx.doi.org/10.1016/j.mce.2012.09.002

Yin, F.G., Zhang, Z.Z., Huang, J., et al., 2010. Digestion rate of dietary starch affects systemic circulation of amino acids in weaned pigs. Brit. J. Nutr., 103(10):1404-1412. http://dx.doi.org/10.1017/S0007114509993321

Yin, Y.L., Yao, K., Liu, Z.J., et al., 2010. Supplementing L-leucine to a low-protein diet increases tissue protein synthesis in weanling pigs. Amino Acids, 39(5):1477-1486. http://dx.doi.org/10.1007/s00726-010-0612-5

Yin, J., Ren, W.K., Liu, G., et al., 2013. Birth oxidative stress and the development of an antioxidant system in newborn piglets. Free Radical Res., 47(12):1027-1035. http://dx.doi.org/10.3109/10715762.2013.848277

Zelnickova, P., Leva, L., Stepanova, H., et al., 2008. Age-dependent changes of proinflammatory cytokine production by porcine peripheral blood phagocytes. Vet. Immunol. Immunopathol., 124(3-4):367-378. http://dx.doi.org/10.1016/j.vetimm.2008.04.016

\section{中文概要}

题 目: 酵母产物对断奶仔猪肠道形态、屏障功能、细胞 因子表达和抗氧化系统的影响

目 的: 验证添加酵母混合物（酵母培养物、酵母细胞壁 水解物和酵母提取物) 对断奶仔猪生长性能、腹 泻发生率、肠道形态、屏障功能、免疫反应和抗 氧化系统的影响。

创新点: 考察酵母培养物、酵母细胞壁水解物和酵母提取 物混合物对断奶仔猪的协同作用。

方 法: 90 头 21 日龄断奶仔猪随机分为 3 组, 分别饲喂 基础日粮（对照组），含 $1.2 \mathrm{~g} / \mathrm{kg}$ 的酵母混合物 (YP 组) 及含 $20 \mathrm{mg} / \mathrm{kg}$ 硫酸粘杆菌素日粮 (CSE 组) 14 天，比较三组间各项指标差异。

结 论: 结果表明, 三组之间平均日采食量、平均日增重 和料肉比无显著差异。YP 组腹泻发生率显著高 于其它两组。对照组十二指肠和空肠的线毛高度 以及十二指肠的隐窝深度显著高于 YP 组和 CSE 组。相对于对照组或 CSE 组, YP 组十二指肠和 空肠线毛淋巴细胞数目显著增加, 而回肠线毛内 淋巴细胞数目显著降低。相对于对照组, YP 组 空肠和回肠内白介素-10（IL-10）的分泌增加, YP 和 CSE 也显著影响了仔猪肠道和血清中抗氧 化因子; YP 和 CSE 组血清 D-乳酸浓度和二胺氧 化酶活性都增强; YP 组或 CSE 组肠道 occludin 和 ZO-1 mRNA 表达降低。综上所述, 酵母混合 物添加会增加断奶仔猪腹江发生率, 并对断奶仔 猪肠道形态学和屏障功能具有副作用。

关键词: 酵母产物; 断奶仔猪; 肠道形态; 屏障功能; 抗 氧化系统 